\title{
Catecholamine Metabolism of a Ganglioneuroma: Correlation with Electronmicrographs
}

\author{
Ira M.Rosenthal [64], Ruven Greenberg, Ralph Kathan, G.S. Falk and Ruth Wong \\ Departments of Pediatrics, Physiology, Biological Chemistry, and Pathology, \\ University of Illinois College of Medicine, Chicago, Illinois, USA
}

\begin{abstract}
Extract
Studies of the catecholamine metabolism in a patient having a functional ganglioneuroma are reported. Biochemical determinations of catecholamines and metabolites were correlated with histochemical and electron microscopic examination of the tumor. Increased urinary excretion of 3-methoxy-4-hydroxy mandelic acid, homovanillic acid, and dopamine was found prior to excision of the tumor. There was no significant increase in excretion of normetanephrine-metanephrine or of norepinephrine-epinephrine. Concentration of norepinephrine and epinephrine in the tumor tissue was $0.095 \mathrm{mg} / \mathrm{g}$. This concentration is greater than that found in neuroblastomas, but less than that found in pheochromocytomas. Normetanephrine-metanephrine was detected in the tumor tissue, indicating degradation of norepinephrine by catechol- $O$-methyl transferase. Computed turnover of norepinephrine in the tumor tissue was 6.85 hours.

Catecholamines were present within heavy mitochondrial fractions prepared from tumor tissue; the spontaneous release of norepinephrine into the suspending medium was determined during incubation under standard conditions. The data indicate that rapid turnover of norepinephrine was not related to accelerated spontaneous release from catecholamine granules. Electron microscopic examination revealed ganglion cells and a complex neuropil. Dense core vesicles were present in many of the neural processes and in ganglion cells. Synaptic junctions between neural processes and between neural processes and ganglion cells were seen. Nerve bundles containing neural processes were present. There was wide variation in the cross sectional diameter of the processes.

The number of Type I dense core vesicles of this ganglioneuroma were decreased in comparison with those found in pheochromocytomas and increased in relation to neuroblastomas.
\end{abstract}

\section{Speculation}

The synapse-like areas of membrane specialization observed in this tumor may have been part of the mechanism by which differentiation of the ganglion cells was directed. The high rate of turnover of catecholamines does not seem to be dependent upon an increased rate of spontaneous release of catecholamines from isolated secretory vesicles. 


\section{Introduction}

Catecholamines are synthesized by some ganglioneuromas; in this respect, these tumors resemble neuroblastomas and pheochromocytomas. Several studies contain data concerning excretion of catecholamines and their metabolites in the urine of patients with ganglioneuromas $[16,19,23,27,28,29,30,41,47$, $54,56]$. In two of these studies detection of norepinephrine (NE) in ganglioneuroma tissue was reported $[19,41]$. We are aware of only a single report concerned with the fine structure of a ganglioneuroma at electron microscopic levels of magnification [40]; however, biochemical studies were not reported.

In the present study, the catecholamine metabolism was examined in a functional ganglioneuroma and correlated with biochemical studies of urine and tumor tissue, as well as with histochemical and electron microscopic examination of the tumor. Biochemical determinations permit calculation of the turnover rate of NE within the tumor. Determination of the turnover rates of $\mathrm{NE}$ and epinephrine (E) have been reported previously for pheochromocytomas, but not for ganglioneuromas or for neuroblastomas [9, 42]. Electronmicrographs of ganglioneuroma tissue in our patient revealed dense core vesicles morphologically similar to those found in adrenal medullary tissue and in pheochromocytoma and neuroblastoma tissue. These vesicles were located within the neural processes and within the tumor cells. The electronmicrographs also revealed axo-dendritic and axo-somatic junctions, some of which were similar in appearance to functional synapses seen in the nervous system $[18,58]$. The catecholamine metabolism of this ganglioneuroma has been compared with that of other catecholamineproducing tissues.

\section{Case Report}

A $31 / 2$-year-old Caucasian boy was admitted to a community hospital with a three-week history of abdominal pain and fever. He had had no diarrhea. Physical examination revealed the presence of a mass in the right lower quadrant. Roentgenographic studies of the gastrointestinal tract were normal, and an intravenous pyelogram revealed no abnormalities. At laparotomy, a firm mass found in the right lower quadrant was biopsied, but because of technical difficulties, was not excised. A diagnosis of ganglioneuroma was made. The child was transferred on May 12, 1965, to the University of Illinois Research and Educational Hospitals for further study and for excision of the tumor.

Physical examination on admission revealed a welldeveloped, cooperative male child. Blood pressure was $100 / 60$. A healing abdominal incision was present.
Despite abdominal tenderness, it was possible to outline an abdominal mass in the right lower quadrant. Blood count and urinalysis were normal. Urinary excretion of catecholamines and their principle metabolites was determined. Excretion of 3-methoxy-4-hydroxy mandelic acid (VMA) and homovanillic acid (HVA) was increased over normal values. The tumor mass was firmly attached to the iliopsoas muscles and measured $6 \times 8 \times 8 \mathrm{~cm}$. Following excision, the child made an uneventful recovery and has remained well. Urinary excretion of catecholamines and metabolites, measured several times following surgery, was normal.

The tumor weighed $37 \mathrm{~g}$. The hematoxylin and eosin-stained sections (fig. 1) revealed many large neural cells. Most of these were mature ganglion cells mixed in with rather abundant capillary blood vessels and connective tissue stroma, which in some parts of the tumor formed a capsule around the neural elements. A large amount of the tumor stroma was fibrillar. Some of the ganglion cells were multinuclear. Several clumps of deeply basophilic cells with scant cytoplasm resembling lymphocytes were seen in the tumor mass. No undifferentiated neural cells, satellite cells, or Schwann cells were present. The tumor had a solitary point of attachment to the underlying tissue. The vascular supply was through small capillaries. The rich neural plexus subsequently observed at electron microscopic levels of magnification was unrecognizable in these sections. Based on the hematoxylin and eosin sections, the tumor was characterized as a ganglioneuroma.

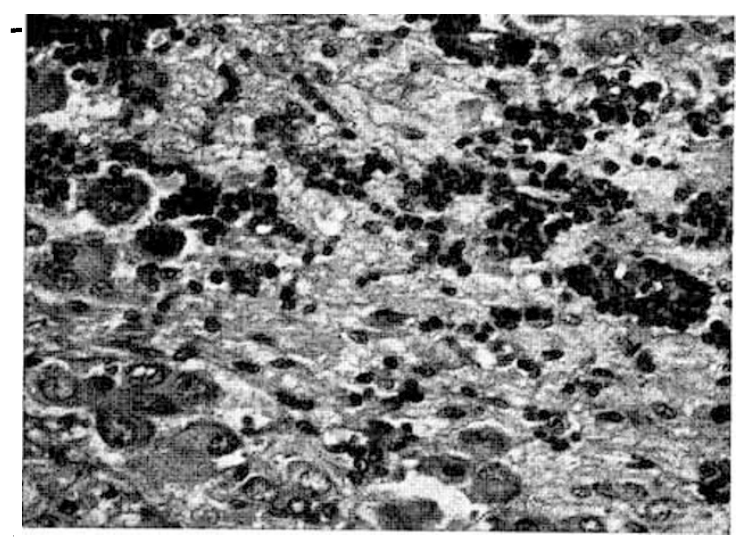

Fig. 1. Hematoxylin-eosin section of ganglioneuroma. $400 \times$. A number of ganglion cells are visualized in the left lower field. The nuclei are located eccentrically within the abundant cytoplasm. A single prominent nucleolus is usually present. Clusters of lymphocytes are noted in the upper portion of the field. Eosinstained fibrillar material and fibrocytes make up the stroma. 
Methods

Determinations were made immediately on 24-hour collections of urine acidified with $6 \mathrm{~N}$ hydrochloric acid. VMA was determined by the method of PISANo et $a l$. [36] and metanephrine-normetanephrine (MN and NMN) by the method of PISANo et al. [35], as modified by CROUT et al. [8]. NE and E were determined by a modification of the trihydroxy-indole reaction using iodine as the oxidant [51]; fluorescence was measured in an Aminco-Bowman spectrophotofluorometer. NE and $\mathrm{E}$ were determined at $\mathrm{pH} 6.5$ and $\mathrm{E}$ at $\mathrm{pH} 3.5$. HVA was measured by the method of SANKOFF and Sourkes [44] or by the method of SATo [45]. Dopamine was determined by a modification of the method of DRUJAN et al. [11].

Aliquots of tumor tissue were homogenized in 10 volumes of $5 \%$ trichloracetic acid; the homogenate was centrifuged at $13,000 \times \mathrm{g}$ for $20 \mathrm{~min}$. The supernatant was analyzed for $\mathrm{NE}$ and $\mathrm{E}$ and for $\mathrm{NMN}$ and $\mathrm{MN}$ by the same method employed for analysis of urine.

Studies were made of the rate of spontaneous release of catecholamines from the sedimented structures contained within the heavy mitochondrial fraction of the tumor tissue. The tumor was minced $(1.5 \mathrm{~g}$ in $2.5 \mathrm{ml}$ phosphate buffer, $125 \mathrm{mM} \mathrm{KCl}, 5 \mathrm{mM} \mathrm{KK_{2 }} \mathrm{PO}_{4}$, $6 \mathrm{mM} \mathrm{MgCl}_{2}, \mathrm{pH} \mathrm{6.5)}$ and homogenized for $2 \mathrm{~min}$ in an Potter-Elvehjem homogenizer (clearance 0.004 to 0.006 inches). The preparation of the heavy mitochondrial fraction, in which the majority of catecholamine granules are present, has been described in experiments with the adrenal medullae of rats [22]. The fraction was resuspended in fresh phosphate buffer and incubated at $37^{\circ}$ for $30 \mathrm{~min}$. Subsequently, it was layered over $0.5 \mathrm{M}$ sucrose. The catecholamine granules, together with the mitochondria, were sedimented at $20,000 \times \mathrm{g}$ in the cold for $20 \mathrm{~min}$. The NE and $\mathrm{E}$ content of the final supernatant and the final centrifugate, performed in duplicate, were determined by the fluorimetric method of SHORE and OLIN [46], as modified by Weigand and Perry [57]. Data were calculated by relating the amount of $\mathrm{NE}$ or $\mathrm{E}$ released into the supernatant to the total present in the combined supernatant and centrifugate. Spontaneous release of NE and $E$ from the tumor sediment was compared with that obtained from rat adrenal medullary granules under comparable conditions [22].

In addition to the hematoxylin and eosin-stained sections, bichromate oxidized sections were prepared [20]. The method used can determine the presence of $\mathrm{NE}$ and $\mathrm{E}$ if there are relatively high concentrations of these compounds. Sections made from tissues fixed in Caulfield's $1 \%$ osmium tetroxide and counterstained with $2 \%$ uranyl acetate were used for electron microscopic studies [3].

Table I. Excretion of catechol metabolites in urine

\begin{tabular}{|c|c|c|c|c|c|c|}
\hline \multirow[t]{2}{*}{ Date } & $\mathrm{VMA}^{1}$ & $\mathrm{NMN}+\mathrm{MN}^{2}$ & $\mathrm{HVA}^{3}$ & $\mathrm{NE}+\mathrm{E}^{4}$ & Dopamine & Creatinine \\
\hline & \multicolumn{6}{|c|}{$\mathrm{mg} / 24 \mathrm{~h}$} \\
\hline $5-13-65$ & 11.6 & 0.59 & 9.0 & 0.012 & 0.250 & 242 \\
\hline 5-14-65 & 14.1 & 1.01 & 12.5 & 0.020 & 0.368 & 273 \\
\hline $5-26-64$ & \multicolumn{6}{|c|}{ Surgery } \\
\hline $5-28-65$ & 3.9 & 0.67 & 4.6 & 0.069 & 0.153 & 278 \\
\hline $5-30-65$ & 2.1 & 0.69 & 3.7 & 0.007 & - & 278 \\
\hline $6-01-65$ & 2.1 & 0.27 & 3.5 & 0.028 & 0.063 & 299 \\
\hline $10-12-65$ & 2.5 & 0.16 & 5.15 & 0.024 & - & 306 \\
\hline $12-11-65$ & 2.8 & 0.46 & 4.1 & 0.015 & - & 286 \\
\hline $6-11-66$ & 2.6 & 0.56 & 8.9 & 0.019 & - & 394 \\
\hline $6-17-67$ & 1.65 & 0.14 & 3.5 & 0.024 & - & 376 \\
\hline $6-22-68$ & 1.92 & 0.46 & 4.4 & 0.031 & - & 419 \\
\hline
\end{tabular}

Amounts of VMA, normetanephrine-metanephrine, homovanillic acid, norepinephrine-epinehrpine, dopamine, and creatinine in 24-hour urine collections before and after surgical excision of the tumor. Upper daily limits for normal in this laboratory for a child of this age are: VMA $3.0 \mathrm{mg}$; NMN+MN $0.7 \mathrm{mg}$; NE+E $0.035 \mathrm{mg}$; HVA $6.0 \mathrm{mg}$. Upper daily limit of dopamine excretion in adults is $0.525 \mathrm{mg}$.

1 3-Methoxy-4-hydroxy mandelic acid.

${ }^{2}$ Normetanephrine-metanephrine.

${ }^{3}$ Homovanillic acid.

${ }^{4}$ Norepinephrine-epinephrine. 


\section{Results}

Results of urine determinations are listed in table I. In preoperative specimens there was an increase over normal levels of VMA, HVA, and dopamine. Excretion of NMN and MN and of NE and $E$ was within normal limits. After excision of the tumor, excretion of VMA, HVA, and dopamine became normal.

Results of the analysis of the tumor for NE, NMN, and $M N$ are listed in table II. There was an appreciable concentration of NE. The low level of $\mathrm{E}$, compared with that of NE, probably represents minimal fluorescence at $\mathrm{pH} 3.5$ of NE rather than the true concentration of $\mathrm{E}$. Low concentrations of NMN and $\mathrm{MN}$ also were found.

By subtracting the amounts of VMA, NMN, and $\mathrm{MN}$ and of $\mathrm{NE}$ and $\mathrm{E}$ found in postoperative urine from amounts found in preoperative urine, the content of these compounds attributable to the metabolism of the tumor was obtained. Dividing this figure by the total value of $\mathrm{NE}$ and $\mathrm{E}$ content within the tumor permitted computation of the turnover rate. This was 6.85 hours [8].

The homogenate, prepared from the tumor tissue to study the rate of release of the catecholamines from the heavy mitochondrial fraction, contained $1.87 \mu \mathrm{g}$ $\mathrm{NE} / \mathrm{ml}$ and trace amounts of $\mathrm{E}(0.09 \mu \mathrm{g} / \mathrm{ml})$, of which $0.7 \mu \mathrm{g} \mathrm{NE}(37 \%$ ) was sedimentable and presumably associated with the catecholamine granules within the heavy mitochondrial fraction. These values are based on only a small percentage of the total catecholamine content of the sample; the major portion of the catecholamines apparently remained behind in the rough fibrous tissue that was not homogenized by the relatively gentle procedures required to preserve the granules.

Data on the spontaneous release of catecholamines from the sedimentable granules of the ganglioneuroma tissue are presented in table III. Sixty-seven percent of the NE content of the tumor granules was released into the medium; under comparable conditions, $86 \%$ of the catecholamine content of rat adrenal medullary granules is released.

In the bichromate oxidized sections, none of the neural cells was stained; only occasional small clumps of red blood cells in capillaries stained brown.

Numerous electronmicrographs were examined. The morphologic features to be discussed are the presence of dense core vesicles in many of the neural processes, the presence of morphologic synaptic junctions between neural processes and tumor cells, and the absence of Schwann and satellite cells.

Large neural cells, 15 to $20 \mu$ in cross section, were present. The ultrastructure of these cells resembled that of mature ganglion cells of human sympathetic ganglia $[5,7,34]$. Small cells, 5 to $8 \mu$ in cross section, were also present. The ultrastructure of the smaller cells was characteristic of lymphocytes; no undifferentiated neural cells were observed. There were many unmyelinated neural processes between cells. The extracellular space between the naked processes was enlarged. Many of the neural processes were distended; some of the larger ones measured as much as 4 to $5 \mu$ in cross section (figs. 2 and 3). Neural filaments, neural tubules, and mitochondria were identified in many of these processes. Moderate numbers of clear vesicles, 400 to $600 \AA$, and less numerous dense core vesicles, 900 to $2000 \AA$, were present in many of the neural processes within the neuropil (figs. 2 and 3) and within the nerve bundles (figs. 4 and 5). The dense core vesicles observed were similar to Type I dense core vesicles reported by Grillo and PALAY [25]. We rarely saw the smaller dense core vesicles (types 2 and 3 , about $450 \AA$ ) normally seen in postganglionic sympathetic terminals [25]. Large dense core vesicles, 900 to

Table II. Content of $\mathrm{NE}$ and $\mathrm{NMN}+\mathrm{MN}$ in tumor and turnover of $\mathrm{NE}$

\begin{tabular}{lc}
\hline Weight of tumor & $37.0 \mathrm{~g}$ \\
Concentration in tumor tissue & \\
$\quad \mathrm{NE}$ & $0.0950 \mathrm{mg} / \mathrm{g}$ \\
$\mathrm{NMN}+\mathrm{MN}$ & $0.0043 \mathrm{mg} / \mathrm{g}$ \\
Total content in tumor tissue & $3.52 \mathrm{mg}$ \\
$\quad \mathrm{NE}$ & $0.16 \mathrm{mg}$ \\
NMN+MN & \\
Preoperative 24-hour urine content of & \\
$\quad$ VMA+(NMN+MN)+(NE) & $15.12 \mathrm{mg}$ \\
Postoperative 24-hour urine content of & \\
$\quad$ VMA+(NMN+MN)+(NE) & $2.79 \mathrm{mg}$ \\
Urine content of VMA+(NMN+MN) + \\
$\quad$ NE) attributed to tumor & $12.33 \mathrm{mg}$ \\
Computed turnover of NE & $6.85 \mathrm{~h}$ \\
\end{tabular}

Table III. Catechol release by mitochondria

\begin{tabular}{lc}
\hline $\begin{array}{l}\text { Heavy mitochondrial fraction } \\
\text { obtained from }\end{array}$ & $\begin{array}{c}\% \text { Catecholamines } \\
\text { released }\end{array}$ \\
\hline
\end{tabular}

Ganglioneuroma tissue $\quad 67$

Adrenal medullary tissue (rat) $\quad 86$

Percent of catecholamines released from sedimentable structures contained in the heavy mitochondrial fraction during incubation at $37^{\circ}$ for $30 \mathrm{~min}$ and suspended in a fresh phosphate buffer (see text). 


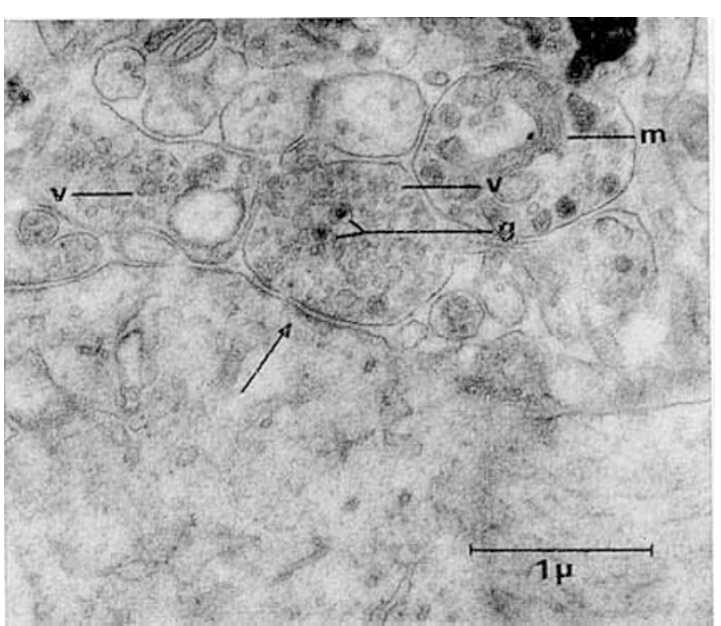

Fig.2. Axo-dendritic synapse (arrow) within ganglioneuroma. There is a symmetrically increased amount of electron dense material associated with the pre- and post-synaptic membranes. The synaptic cleft also contains some electron dense material; it is $400 \AA$ wide. Note presence of clear vesicles (v), Type 1 dense core vesicles $(\mathrm{g})$, and mitochondria $(\mathrm{m})$ in the nerve terminals.

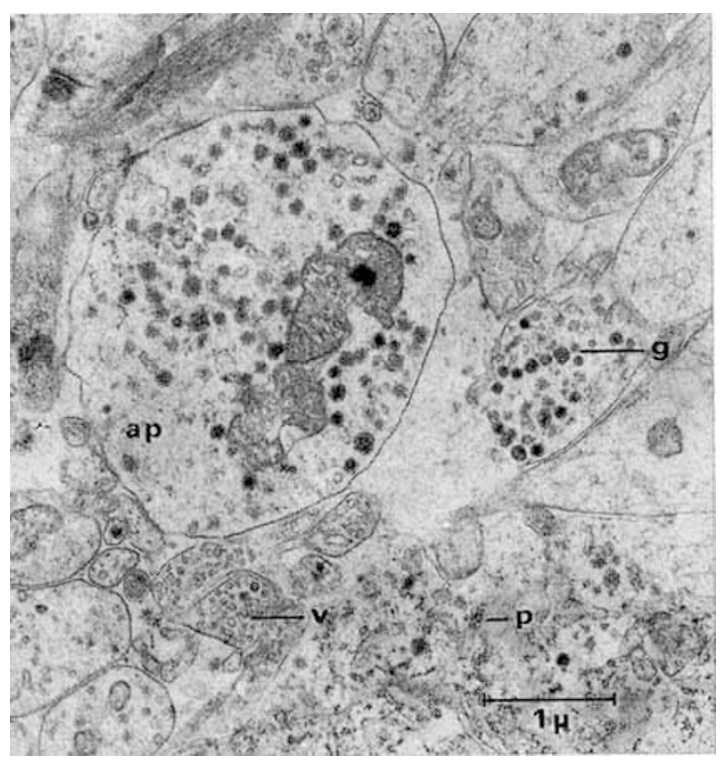

Fig.3. Neuropil containing unusually large axon process (ap), measuring $3 \times 3 \mu$ in cross-section. There was wide variation in the relative numbers of clear vesicles (v) and dense core vesicles ( $g$ ) in the various axon processes. Note the frequent clusters of ribosomes $(p)$ in the perinuclear cytoplasm of a ganglion cell in the lower portion of the figure.

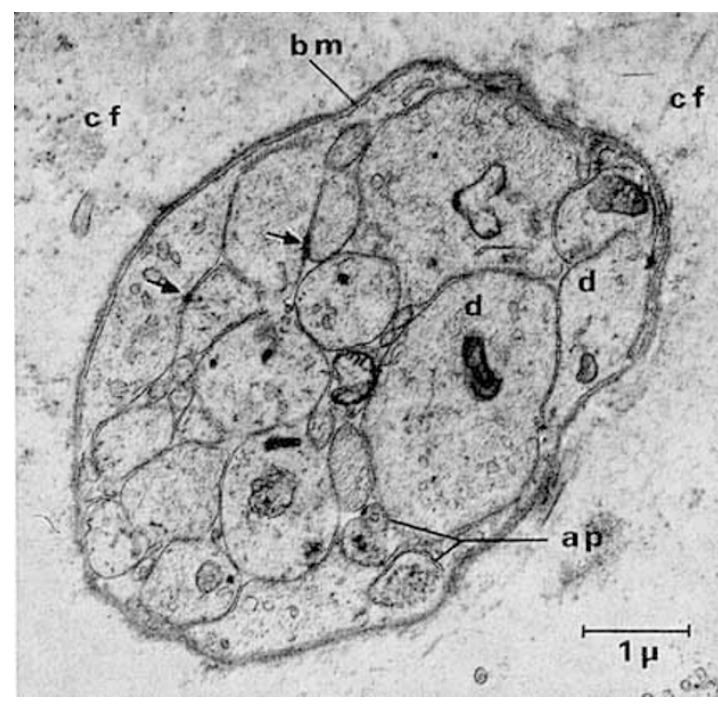

Fig.4. Large nerve bundle containing several small axon processes (ap) and many dendritic processes (d). Several membrane contact zones between dendritic processes are present (see arrows). A wide basement membrane (bm) surrounds the nerve bundle. The spacious ground substance contains collagen fibrils (cf) seen in longitudinal and cross-section.

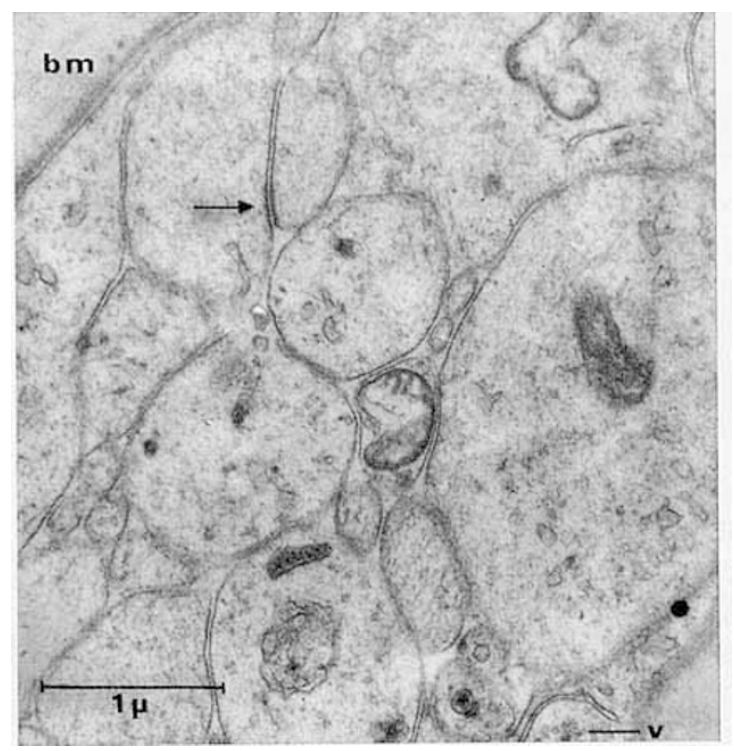

Fig.5. Enlargement of portion of fig. 4. Note basement membrane $(\mathrm{bm})$. Note desmosome-like contact zone (arrow). Note clear vesicles (v) in axon processes. 
$2000 \AA$, were observed also within the perinuclear cytoplasm of the ganglion cells, and in one instance, within a smaller ganglion cell.

There were specialized areas of contact between neural processes and between neural processes and ganglion cells. Some were similar to the desmosomes described in epithelial structures $[13,14]$ (figs. 4 and 5). Others, however, resembled neural synaptic junctions (fig.2), in which presynaptic and postsynaptic membranes are thickened in association with clear vesicles in clusters near the presynaptic membrane thickening. The dense core vesicles were not similarly clustered, but were distributed randomly.

Frequently, naked neural processes were collected into nerve bundles (fig. 4) within an enveloping basement membrane. Usually, the nerve bundles were within the spacious ground substance of the fibrillar and largely acellular portions of the tumor. Although samples were taken from many areas of the tumor, cytoplasmic extensions forming from any of the cells were rarely seen; therefore, the cell of origin of the numerous neural processes within the neuropil and the nerve bundles remains uncertain. Many of the neural processes within the bundles were devoid of the usual organelles that enable axonic or dendritic identification. The processes varied widely in cross sectional diameter, 0.5 to $5.0 \mu$. In the absence of clear or dense core vesicles, these processes were considered to be dendritic.

Fibrocytes, collagen fibrils, small blood vessels, degenerating neural cells, and occasional myelin figures were noted. No satellite or Schwann cells were observed by light microscopy nor were these cells seen by electron microscopy.

\section{Discussion}

Increased excretion of catecholamines and related metabolites in urine has been found in a number of patients with ganglioneuroma $[16,19,23,27,28,29,30$, $41,47,54,56]$; however, such an increase has not been found in all cases of ganglioneuroma. KASER [27] reported normal urine VMA excretion in several patients with ganglioneuroma; however, values for urinary excretion of NE, dopamine, DOPA, HVA, and of NMN and MN were not reported. Urinary excretion of catecholamines and related metabolites reported in cases of ganglioneuroma are summarized in table IV. The numerical values are not entirely comparable because of the variety of methods employed for analysis. A compilation of normal values for children reported by Voorhess [55] and Grruow et al. [15] is listed in table V. Some of the ganglioneuromas apparently synthesized excessive quantities of $\mathrm{NE}$, as indicated by in- creased urinary excretion of this compound and its major metabolite, VMA. Increased excretion of HVA in several cases indicated that dopamine and DOPA, intermediates in the synthesis of NE, were released from the tumor and metabolized elsewhere or, alternatively, were degraded within the tumor and then released. In this respect, ganglioneuromas are more similar to neuroblastomas than to pheochromocytomas [54]. Increased excretion of NMN and $M N$ is found uniformly in patients with pheochromocytoma, but may not be found in patients with neuroblastoma or ganglioneuroma, despite a marked increase in VMA excretion [43]. Determination of catecholamines and related derivatives in urine can be of value in the diagnosis of ganglioneuromas. Diagnosis of neuroblastoma, however, cannot be made on the basis of such studies. Analysis of urine for catecholamines and related derivatives can be of value in determining whether complete excision of the tumor has been accomplished. Diarrhea may be present in patients with functional ganglioneuromas [41]. The present study demonstrates that a patient with a functional ganglioneuroma may be asymptomatic despite the abnormal catecholamine metabolism of the tumor.

Little information concerning concentrations of $\mathrm{NE}$, $\mathrm{E}, \mathrm{DOPA}$, dopamine, and of NMN and $\mathrm{MN}$ in the tumor tissue of ganglioneuromas has been published. The available data are summarized in table VI. The concentration of NE, if detected, appears to be relatively low. It is in the same range as that found in neuroblastomas and is thus much lower than that found in pheochromocytomas. The concentration in the tumor reported in this study was higher than that of the two other cases of ganglioneuroma in which NE was detected. In our patient, detectable amounts of NMN and $M N$ were found, indicating degradation of NE within the tumor tissue by catechol-O-methyl transferase. The ganglioneuroma present resembled both neuroblastomas and pheochromocytomas [43].

The low concentration of NE in the ganglioneuroma and the marked increase in such urinary metabolites as VMA indicated that in these functional tumors there is a rapid rate of turnover of $\mathrm{NE}$ within the tumor. The rate obtained, 6.85 hours, is in the same range as that obtained in a number of neuroblastomas [43]. In contrast, although a rapid rate of turnover of NE and $\mathrm{E}$ in this range may be found occasionally in pheochromocytomas, it is generally of a lower order of magnitude $[9,42]$. In the present study, the rapid turnover found in the ganglioneuroma was in the range obtained for NE within the nervous system [53]. The turnover in the adrenal medulla of the rat is in the range of 8 to 12 days for $50 \%$ of the $\mathrm{E}$ [52].

The release of NE (67\%) from the sedimentable tumor granules is slightly lower than that found in rat 
Table IV. Excretion of catecholamines and metabolites in urine of reported cases of ganglioneuroma

\begin{tabular}{|c|c|c|c|c|c|c|c|c|c|c|c|c|c|}
\hline \multirow[t]{2}{*}{ Cases } & \multicolumn{2}{|c|}{$\mathrm{VMA}^{1}$} & \multicolumn{2}{|c|}{$\mathrm{NE}^{2}+\mathrm{E}^{3}$} & \multirow{2}{*}{\multicolumn{2}{|c|}{$\begin{array}{l}\frac{\mathrm{NMN}^{4}+\mathrm{MN}^{5}}{\mu \mathrm{g} / \mathrm{mg} \mathrm{mg} / 24 \mathrm{~h}} \\
\text { creatinine }\end{array}$}} & \multicolumn{2}{|c|}{$\mathrm{HVA}^{6}$} & \multicolumn{2}{|c|}{$\mathrm{DOPA}^{7}$} & \multicolumn{2}{|c|}{ Dopamine } & \multirow{2}{*}{$\begin{array}{l}\text { Age, } \\
\mathrm{yr}\end{array}$} \\
\hline & \multicolumn{2}{|c|}{$\begin{array}{l}\mu \mathrm{g} / \mathrm{mg} \mathrm{mg} / 24 \mathrm{~h} \\
\text { creatinine }\end{array}$} & \multicolumn{2}{|c|}{$\begin{array}{l}\mu \mathrm{g} / \mathrm{mg} \mathrm{mg} / 24 \mathrm{~h} \\
\text { creatinine }\end{array}$} & & & \multicolumn{2}{|c|}{$\begin{array}{l}\overline{\mu \mathrm{g} / \mathrm{mg} \mathrm{mg} / 24 \mathrm{~h}} \\
\text { creatinine }\end{array}$} & \multicolumn{2}{|c|}{$\begin{array}{l}\mu \mathrm{g} / \mathrm{mg} \mathrm{mg} / 24 \mathrm{~h} \\
\text { creatinine }\end{array}$} & \multicolumn{2}{|c|}{$\begin{array}{l}\mathrm{h} \mu \mathrm{g} / \mathrm{mg} \mathrm{mg} / 24 \mathrm{~h} \\
\text { creatinine }\end{array}$} & \\
\hline GREENBERG and Gardner [19] & 25.90 & - & - & $\begin{array}{l}0.148 \\
0.232\end{array}$ & - & - & 402 & 58 & - & - & - & 2.83 & 2.5 \\
\hline Rosenstein and Engelman [41] & 32 & - & 0.41 & - & 3.2 & - & - & - & 5.9 & - & 25.2 & - & $\begin{array}{c}15 \\
\text { months }\end{array}$ \\
\hline $\begin{array}{l}\text { Von STUdNITZ, KASER and } \\
\text { SJOERDSMA [54] }\end{array}$ & 42 & - & 0.40 & - & 3.1 & - & - & - & 5.0 & - & 52.2 & - & $\begin{array}{c}15 \\
\text { months }\end{array}$ \\
\hline KonTRAS $[29]$ & 20 & - & - & - & - & - & - & - & - & - & - & - & 3 \\
\hline $\begin{array}{l}\text { Käser, BETtex and von Studnitz, } \\
6 \text { cases [28] }\end{array}$ & Norm. & - & - & - & - & - & Norm. & - & - & - & - & - & $\begin{array}{l}\text { not } \\
\text { given }\end{array}$ \\
\hline Käser, 8 cases [27] & $\begin{array}{l}\text { Incr. } \\
2 \text { of } 8 \\
\text { cases }\end{array}$ & - & - & - & - & - & $\begin{array}{l}\text { Incr. } \\
1 \text { of } 6 \\
\text { cases }\end{array}$ & - & - & - & $\begin{array}{l}\text { Incr. } \\
1 \text { of } 6 \\
\text { cases }\end{array}$ & - & $\begin{array}{c}\text { not } \\
\text { given }\end{array}$ \\
\hline VOORHESS and GARDNER [56] & - & 6.0 & - & 0.232 & - & 0 & - & - & - & - & - & - & 8 \\
\hline SNELLIE and SANDLER [47] & - & 14.6 & - & 0.270 & - & 45 & - & 50.0 & - & 0.7 & - & 9.5 & 2.5 \\
\hline LEBOEUF et al. $[30]$ & $23-76$ & - & - & - & - & - & - & - & - & - & - & - & 3.5 \\
\hline GreER et al., 2 cases [23] & 15 & - & 0.045 & - & - & - & 60 & - & $<0.05$ & - & 0.33 & - & 3 \\
\hline & 14 & - & - & - & - & - & 30 & - & - & - & - & - & 7 \\
\hline GJEssing, 2 cases $[16]$ & 42 & - & - & - & 0.7 & - & 125 & - & - & - & - & - & 4 \\
\hline & 5 & - & - & - & 3.0 & - & 20 & - & - & - & - & - & 18 \\
\hline Present case & 51.6 & 14.4 & 0.07 & 0.020 & 3.7 & 1.01 & 45.8 & 12.5 & - & - & 1.3 & 0.36 & 3.5 \\
\hline Normals, von STUDNITz, et al. [54] & $<9.5$ & - & $<0.049$ & - & $<2.1$ & - & $<39.9$ & - & $<0.071$ & - & $<0.259$ & - & \\
\hline Normal (adult) (authors' lab) & - & $<6.0$ & - & $<0.090$ & - & $<1.5$ & - & $<10.0$ & - & - & $<0.525$ & - & \\
\hline
\end{tabular}


adrenal medullary granules $(86 \%)$. Similar slow rates of release were reported for the sedimentable structures prepared from pheochromocytomas and neuroblastomas [21]. STJÄRNE et al. [50] have also reported a slow rate of release from pheochromocytoma granules. Presumably, the increased turnover rate of $\mathrm{NE}$ in this tumor was not a function of an accelerated spontaneous release from the catecholamine granules. It is possible that we selected a population of granules with a slow rate of spontaneous release and selectively disrupted the more fragile catecholamine granules that normally exhibit higher rates of spontaneous release. Alternatively, a major population of catecholamine granules, which may have been different, were not examined since these granules remained with the coarse connec- tive tissue elements that were separated from the homogenate.

The spontaneous release of catecholamines from the sedimentable tumor granules and adrenal medullary granules [22] is only $1 / 10$ that of nerve transmitter granules prepared from autonomic nerves [49]. In contrast, with respect to turnover of catecholamines, we have reported previously that ganglioneuroma was unlike adrenal tissue, but was rather like neural tissue. The tumor shares some of the qualities of both chromaffin and neural tissues.

In the present study, bichromate oxidized preparations of the tumor were negative. Sympathetic ganglion cells and related processes are known to be negative when this technique is used. Presumably, the cate-

Table $V$. Excretion of catechol metabolites in urine

\begin{tabular}{|c|c|c|c|c|c|c|}
\hline \multirow{2}{*}{$\begin{array}{l}\text { Age, } \\
\text { yr }\end{array}$} & \multicolumn{2}{|c|}{$\mathrm{VMA}^{1}$} & \multirow{2}{*}{$\begin{array}{l}\mathrm{NE}+\mathrm{E}^{2} \\
\mathrm{mg} / 24 \mathrm{~h}\end{array}$} & \multirow{2}{*}{$\begin{array}{c}\mathrm{NMN}+\mathrm{MN}^{3} \\
\mu \mathrm{g} / \mathrm{mg} / \\
\text { creatinine }\end{array}$} & \multirow{2}{*}{$\begin{array}{c}\mathrm{HVA}^{4} \\
\mu \mathrm{g} / \mathrm{mg} / \\
\text { creatinine }\end{array}$} & \multirow{2}{*}{$\begin{array}{c}\text { Dopamine } \\
\mathrm{mg} / 24 \mathrm{~h}\end{array}$} \\
\hline & $\begin{array}{c}\mu \mathrm{g} / \mathrm{mg} / \\
\text { creatinine }\end{array}$ & $\mathrm{mg} / 24 \mathrm{~h}$ & & & & \\
\hline $0-1$ & & $0.569 \pm 0.309$ & $0.0119 \pm 0.0036$ & & & $0.0609 \pm 0.0243$ \\
\hline $1-5$ & & $1.348 \pm 0.443$ & $0.0220 \pm 0.0075$ & & & $0.1241 \pm 0.0407$ \\
\hline $6-15$ & & $2.373 \pm 0.698$ & $0.0422 \pm 0.0168$ & & & $0.1693 \pm 0.0726$ \\
\hline $15+$ & & $3.192 \pm 0.669$ & $0.0518 \pm 0.0160$ & & & $0.2491 \pm 0.0749$ \\
\hline $1 / 12-1$ & $6.9 \pm 3.2$ & & & $1.64 \pm 1.32$ & $12.9 \pm 9.58$ & \\
\hline $1-2$ & $4.6 \pm 2.2$ & & & $1.68 \pm 1.13$ & $12.6 \pm 6.26$ & \\
\hline $2-5$ & $3.95 \pm 1.72$ & & & $1.25 \pm 0.77$ & $7.58 \pm 3.56$ & \\
\hline $5-10$ & $3.3 \pm 1.4$ & & & $1.13 \pm 0.78$ & $4.7 \pm 2.66$ & \\
\hline $10-15$ & $1.91 \pm 0.77$ & & & $0.60 \pm 0.48$ & $2.5 \pm 2.42$ & \\
\hline $15-18$ & $1.34 \pm 0.61$ & & & $0.24 \pm 0.23$ & $1.0 \pm 0.65$ & \\
\hline
\end{tabular}

Reported normal values for children after Voorhess [55] and GrrLow et al. [15]. Values given by Voorhess are above the dotted line and those of Grroow are below the dotted line.

1 3-Methoxy-4-hydroxy mandelic acid.

2 Norepinephrine-epinephrine.

${ }^{3}$ Normetanephrine-metanephrine.

${ }^{4}$ Homovanillic acid.

Table VI. Concentrations of catecholamines and related compounds in ganglioneuroma

\begin{tabular}{lcccccc}
\hline Authors & $\begin{array}{c}\text { Weight of } \\
\text { tumor, } \mathrm{g}\end{array}$ & $\begin{array}{c}\mathrm{NE} \\
\mu \mathrm{g} / \mathrm{g}\end{array}$ & $\begin{array}{c}\mathrm{E}, \\
\mu \mathrm{g} / \mathrm{g}\end{array}$ & $\begin{array}{c}\text { Dopamine, } \\
\mu \mathrm{g} / \mathrm{g}\end{array}$ & $\begin{array}{c}\text { DOPA, } \\
\mu \mathrm{g} / \mathrm{g}\end{array}$ & $\begin{array}{c}\text { NMN+MN, } \\
\mu \mathrm{g} / \mathrm{g}\end{array}$ \\
\hline GrEENBERG and GARDNER [19] & 42 & 8.6 & 0.07 & 2.09 & -1 & $\mathrm{ND}^{2}$ \\
Rosenstern and ENGELMAN [41] & 56 & 10.4 & - & 1.83 & 0.72 & - \\
GJESSING [16] & $?$ & $\mathrm{ND}$ & $\mathrm{ND}$ & $\mathrm{ND}$ & - & - \\
Present case & 37 & 95.0 & $\mathrm{ND}$ & 3.0 & - & 4.3 \\
\hline
\end{tabular}

1 -: apparently not performed.

2 ND: none detected. 
cholamines were in insufficient concentration in this tumor to be demonstrated by this method.

The electronmicrographs were instructive in several respects. The large neural cells resembled mature sympathetic ganglion cells. The neural cells in neuroblastomas were less differentiated; pheochromocytoma cells were otherwise differentiated. As compared with pheochromocytomas, there were several notable differences. Type I dense core vesicles were reduced in number in the perinuclear cytoplasm of ganglioneuroma cells, and there was a rich neuropil, whereas neural processes are nonexistent in the pheochromocytoma $[1,32,33$, 42]. As compared with neuroblastomas [17, 31, 32, 43], Type 1 dense core vesicles were few or absent in the perinuclear cytoplasm of the neuroblastoma; there was a rich neuropil in both tumors. There were many Type 1 dense core vesicles in the processes of the ganglioneuroma and only occasional or no such vesicles in neuroblastoma processes.

The presence of neural processes within ganglioneuromas, ganglioneuroblastomas, and neuroblastomas has been demonstrated previously by silver-staining techniques [39]; the great abundance of neural processes has now been demonstrated by electron microscopy [31, 32, 40, 43, 48]. We are unaware of any previous report of well-differentiated synapses between neural processes and between neural processes and ganglioneuroma cells; however, there have been reports of less differentiated synapse-like membrane contact zones in a neuroblastoma [31] and in ganglioneuroblastomas $[32,48]$. Thus, it is possible that neural impulses are conducted over neural circuits assumed to exist within these tumors. Conceivably, in this study, the high turnover rate of NE (6.85 hours) may have been the result of interneural traffic. Alternatively, it is possible that the synapses subserve trophic functions, and one tumor cell may regulate the differentiation or metabolism of other tumor cells.

The Type 1 dense core vesicles present within many of the neural processes are similar to those present within the presynaptic boutons of sympathetic ganglia of amphibia [25]; however, these vesicles are virtually absent in unmyelinated fibers of human sympathetic ganglia [34]. Similar dense core vesicles have been reported previously in rare ganglion cells in man [7] and in the rat [24]. Although Griclo [24] believes that most sympathetic ganglion cells lack the granules or vesicles that can be seen in the related synaptic boutons, we observed the contrary. The neural processes of the present tumor probably originated in the predominant ganglion cells, resulting in the similarity of the granules within the perikarya and the neural processes. ROBERTSON et al. [40] have reported the presence of similar large dense core vesicles within the perikaryal cytoplast [61] and, less frequently, within neural pro- cesses of a central ganglioneuroma. In previously reported electronmicrographs of ganglioneuroblastomas containing large ganglion cells, comparable cells contained similar dense core vesicles within the perikarya and the neural processes [32, 48].

According to Richardson [37], Type 1 dense core vesicles accompany clear vesicles (400 to $600 \AA$ ) and perhaps are a characteristic feature of cholinergic autonomic terminals. In the absence of extrinsic innervation, as judged macroscopically, the presence of so numerous a network of cholinergic preterminals is unlikely.

The smaller (about $450 \AA$ ) Types 2 and 3 dense core vesicles reported by GrILlo and PALAY [25] and considered to be characteristic of adrenergic autonomic terminals [10] were rarely seen. There is evidence in support of the association of the smaller dense core vesicles with NE [59]. In the present study, some of the small clear vesicles present within the nerve terminals (figs. 3 and 4) might have contained dense core material not preserved by the standard $\mathrm{OsO}_{4}$ fixation. RICHARDson [38] has obtained better preservation of the dense core material of these vesicles using a potassium permanganate fixation procedure. Use of this procedure would be desirable for future studies of this type of tumor. It is likely that the Type 1 dense core vesicles within axon terminals may also contain NE $[26,60]$. Larger (900 to $2500 \AA$ ) dense core vesicles of adrenal medullary cells are known to contain catecholamines $[4,12]$.

In the present study, the increased diameter of many of the axonal processes, which frequently measured 2 to $5 \mu$ in cross section was noted (figs. 2 to 5 ). Perhaps the absence of Schwann cells, which normally are continually wrapping around the neural processes, permitted the growing processes of the tumor to enlarge inordinately rather than to form into smaller and smaller processes [6].

The absence of satellite and Schwann cells in ganglioneuromas have been described in studies using light microscopy [2] and electron microscopy [40].

In the present study, we had an uncommon opportunity to observe ultrastructural manifestations of the ability of cells derived from the neural crest to differentiate, organize, and secrete catecholamines. Nevertheless, highly differentiated ganglion cells were developed in association with a rich neuropil containing synaptic junctions. These data should be considered in studying the relation of the functional roles of neural supporting cells to mesenchymal cells during and after neural differentiation. Clarification of the complex mode of differentiation of these cells may permit development of methods to convert malignant cells of some neuroblastomas to benign ganglioneuromas, a process which occurs spontaneously in some cases. 
Summary

A child with a functional ganglioneuroma was studied. The tumor caused excessive urinary excretion of VMA, HVA, and dopamine. Analyses of the tumor revealed significant concentrations of NE, dopamine, NMN, and NM. The calculated turnover of NE within the tumor was 6.85 hours. Electron micrographs of the tumor revealed similar dense core vesicles, 900 to 2000 $\AA$, in the perikaryon and the neural processes. Clear vesicles, $500 \AA$, were also present in neural processes. Axo-dendritic and axo-somatic sites of membrane specialization were observed. Well-differentiated morphologic synapses have not been reported previously in ganglioneuromas. The catecholamine metabolism and electron microscopic appearance of the ganglioneuroma have been compared with that of neuroblastomas and pheochromocytomas, which also synthesize and degrade catecholamines.

\section{References and Notes}

1. BAsSLER, R. und Habighorst, L.V.: Vergleichende licht- und elektronenmikroskopische Untersuchungen am Nebennierenmark und Phaochromocytom. Beitr.path. Anat. 130: 446 (1964).

2. Carpenter, W.B. and Kernohan, J.W.: Retroperitoneal ganglioneuromas and neurofibromas. Cancer 16: 788 (1963).

3. Caufield, J.B.L.: Effects of varying the vehicle for osmium tetroxide in tissue fixation. J. Biophys. Biochem. Cytol. 3: 827 (1957).

4. Coupland, R.E.: Electron microscopic observations on the structure of the rat adrenal medulla. I. The ultrastructure and organization of chromaffin cells in the normal adrenal medulla. J. Anat. 99: 231 (1965).

5. CRAvioto, H.: Elektronenmikroskopische Untersuchungen am sympathischen Nervensystem des Menschen. 1. Nervenzellen. Z.Zellforsch. 58: 312 (1962).

6. CRavioto, H.: The role of Schwann cells in the development of human peripheral nerves. J. Ultrastruct. Res. 12: 634 (1965).

7. Gravioto, H. und Merker, H.J.: Elektronenmikroskopische Untersuchungen an Satellitenzellen des sympathischen Ganglion des Menschen. Arch.Psychiat.Z.ges. Neural. 204: 1 (1963).

8. Grout, R.; Pisano, J. and Sjoerdsma, A. : Urinary excretion of catecholamines and their metabolites in pheochromocytoma. Amer.Heart J. 61: 375 (1961).

9. Crout, J.R. and SJoerdsma, A.: Turnover and metabolism of catecholamines in patients with pheochromocytoma. J. Clin. Invest. 43: 94 (1964). 10. De Robertis, E. and Pellegrino de Iraldi, A.: Plurivesicular secretory processes and nerve endings in the pineal gland of the rat. J. Biophys. Biochem. Cytol. 10: 361 (1961).

11. Drujan, B.D.; Sourkes, T.L.; Layne, D.S. and Murphy, G.F.: The differential determination of catecholamines in urine. Canad.J.Biochem. Physiol. 37: 1153 (1959).

12. Elfvin, L. G.: The fine structure of the cell surface of chromaffin cells in the rat adrenal medulla. J. Ultrastruct. Res. 12: 263 (1965).

13. Farquhar, M.G. and Palade, G. E.: Junctional complexes in various epithelia. J. Cell Biol. 17: 375 (1963).

14. Farquhar, M.G. and Palade, G.E.: Gell junctions in amphibian skin. J. Cell Biol. 26: 263 (1965).

15. Gitlow, S.E.; Mendlowitz, M.; Wilk, E.K.; WiLK, S.; Wolf, L. and Bertan, L. M.: Excretion of catecholamine catabolites by normal children. J.lab.clin. Med. 72: 612 (1968).

16. GJessing, L.R.: Studies of functional neural tumors. Scand.J.clin. Lab. Invest. 16: 661 (1964).

17. Goldstein, M.N.; Burdman, J.A. and Journey, L. J. : Long term tissue culture of neuroblastomas. II. Morphologic evidence for differentiation and maturation. J. Nat. Cancer Inst. 32: 165 (1964).

18. GRAY, E.G.: Ultra-structure of synapses of the cerebral cortex and of certain specializations of neuroglial membranes; in: J.D.Boyd Electron microscopy in anatomy, pp. 54-73 (Williams and Wilkins, Baltimore 1961).

19. Greenberg, R.E. and Gardner, L.I.: Catecholamine metabolism in a functional neural tumor. J. clin. Invest. 39: 1729 (1960).

20. Greenberg, R.; Jeffay, A. I. and Toman, J. E. P.: Histological evidence for a neural role in the depletion of adrenal catecholamines by deserpidine and TM-10. J.Pharmacol.exp.Ther. 130: 119 (1960).

21. Greenberg, R. and Rosenthal, I. M.: Rate of release of catecholamines from sedimentable structures of human tumor tissues. Proc. 23rd int. Congr. Physiological Science, p. 486 (1965).

22. Greenberg, R. and Sabelli, H.C.: Drug effects on epinephrine release from rat adrenal medulla homogenates and granule preparations. Proc. Soc. exp. Biol. N.Y. 116: 705 (1964).

23. Greer, M.; Anton, A.H.; Williams, G. M. and EcheVARRIA, R. A.: Tumors of neural crest origin. Biochemical and pathological correlation. Arch. Neurol. 13: 139 (1965).

24. Grillo, M.A.: Electron microscopy of sympathetic tissues. Pharmacol. Rev. 18: 387 (1966).

25. Grillo, M.A. and Palay, S. L.: Granule contain- 
ing vesicles in the autonomic nervous system; in: S.S. BReEse Vth int. Congr. of E. M., Philadelphia, Vol.2, U-1 (Academic Press, New York/London 1962).

26. Hokfelt, T.: On the ultrastructural localization of noradrenaline in the central nervous system of the rat. Z.Zellforsch. 79: 110 (1967).

27. KäSER, H.: Gatecholamine producing neural tumors other than pheochromocytoma. Pharmacol. Rev. 18: 659 (1966).

28. Käser, H.; Bettex, M. and von Studnitz, W.: Further observations on the determination of catecholamine metabolites in tumours of sympathetic nervous system. Arch. Dis. Childh. 39: 168 (1964).

29. Kontras, S. B. : Urinary excretion of 3-methoxy-4hydroxymandelic acid in children with neuroblastoma. Cancer 15: 978 (1962).

30. Leboeuf, G.; Eberlein, W.R.; Stremker, D.D. and Bongrovann, A.M.: Functioning ganglioneuroma, celiac syndrome and renal acidosis. Amer.J. Dis. Child 102: 693 (1961).

31. LuSE, S.A.: Synaptic structures occurring in a neuroblastoma. Arch. Neurol., Chicago 11: 185 (1964).

32. Mrsugr, K.; Mrsugr, N. and Newton, W.A.: Fine structural study of neuroblastoma, ganglioneuroblastoma and pheochromocytoma. Arch. Path. 86: 160 (1968).

33. PAGE, L.B. and JAcoBy, G.A.: Catecholamine metabolism and storage granules in pheochromocytoma and neuroblastoma. Medicine 43: 379 (1964).

34. Pick, J.; DeLemos, C. and Gerdin, C.: The fine structure of sympathetic neurons in man. J. comp. Neurol. 122: 19 (1964).

35. Pisano, J.: Simple analysis of normetanephrine and metanephrine in urines. Clin.chim. Acta 5: 406 (1960).

36. Pisano, J.; Crout, R. and Abraham, D.: Determination of 3-methoxy-4-hydroxymandelic acid in urine. Clin. chim. Acta 7: 285 (1962).

37. Richardson, K.G.: The fine structure of the albino rabbit iris with special reference to the identification of adrenergic and cholinergic nerves and nerve endings in its intrinsic muscles. Amer.J. Anat. 114: 173 (1964).

38. Richardson, K. G.: Electron microscopic identification of autonomic nerve endings. Nature, Lond. 210: 756 (1966).

39. Rio-HortegA, P. DEL: The microscopic anatomy of tumors of the central and peripheral nervous system (Thomas, Springfield, Ill. 1962).

40. Robertson, D. M.; Hendry, W.S. and Vogel, F. S.: Central ganglioneuroma: A case study using electron microscopy. J. Neuropath. exp. Neurol. 23: 692 (1964).

41. Rosenstein, B.J. and Engelman, K. : Diarrhea in a child with a catecholamine secreting ganglioneuroma. J. Pediat. 63: 217 (1963).

42. Rosenthal, I.M.; Greenberg, R.; Goldstein, R.; Kathan, R. and Gadkin, L.: Gatecholamine metabolism in a pheochromocytoma. Amer.J.Dis. Child. 112: 389 (1966).

43. Rosenthal, I.; Greenberg, R. and Kathan, R. (In preparation.)

44. Sankoff, I. and Sourkes, T.L.: HVA by thin layer chromatography. Canad.J. Biochem. 41: 1381 (1963).

45. Sato, T.L.: The quantitative determination of 3methoxy-4-hydroxyphenylacetic acid (HVA) in urine. J.lab. clin. Med. 66: 517 (1965).

46. SHORE, P.A. and OLIN, J.S.: Identification and chemical assay of norepinephrine in brain and other tissues. J.Pharmacol. exp.Ther. 122: 295 (1958).

47. SNellite, J.M. and SANDler, M.: Secreting intrathoracic ganglioneuroma. Proc. roy. Soc. Med. 54: 327 (1961).

48. Staley, N.A.; Polesky, H.F. and Bensch, K. G.: Fine structural and biochemical studies on the malignant ganglioneuroma. J.Neuropath. exp. Neurol. 26: 634 (1967).

49. STJÄRNE, L.: Studies of catecholamine uptake storage and release mechanisms. Acta physiol. scand. 62: Suppl. 228 (1964).

50. Stjärne, L.; Euler, U.S. v. and Lishajko, F.: Catecholamines and nucleotides in phaeochromocytoma. Biochem. Pharmacol. 13: 809 (1964).

51. Udenfriend, S.: Fluorescence assay in biology and medicine; pp. 140-148 (Academic Press, London 1962).

52. Udenfriend, S.; Cooper, J.R.; Glark, G.T. and BAER, J.E.: Rate turnover of epinephrine in the adrenal medulla. Science 117: 663 (1953).

53. Udenfriend, S. and ZaLtzman-Nirenberg, P.: Norepinephrine and 3,4-dihydroxy-phenethylamine turnover in guinea pig brain in vivo. Science 142: 394 (1963).

54. Von Studnitz, W.; Kaser, H. and SJoerdsma, A. : Spectrum of catecholamine biochemistry in patients with neuroblastoma. New Engl.J. Med. 269: 232 (1963).

55. VooRHess, M.L.: Urinary catecholamine excretion by healthy children. I. Daily excretion of dopamine, norepinephrine, epinephrine and 3-methoxy-4-hydroxymandelic acid. Pediatrics 39: 252 (1967).

56. Voorhess, M.L. and Gardner, L.I.: Studies of catecholamine excretion by children with neural 
tumors. J. clin. Endocrin. 22: 126 (1962).

57. Weigand, R.G. and Perry, J.E.: Effects of LDOPA and N-methyl-N-benzyl-2-propynylamine HCL on DOPA, dopamine, norepinephrine and serotonin levels in mouse brain. Biochem. Pharmacol. 7: 181 (1961).

58. Whittaker, V.P. and Gray, E.G.: The synapse: biology and morphology. Brit. med. Bull. 18: 223 (1962).

59. Wolfe, D.E.; Potter, L.T.; Richardson, K.C. and AxElRod, J.: Localizing tritiated norepinephrine in sympathetic axons by electron microscopic autoradiography. Science 138: 440 (1962).

60. Zambrano, D.: On the presence of neurons with granulated vesicles in the median eminence. Neu- roendocrinology 2: 141 (1968).

61. Based on the published electronmicrographs (fig. 6 , Ref. 40 ), we would interpret the presence of many dense core vesicles within an invaginated neural process and fewer in the perikaryon.

62. This study was supported by National Institutes of Health Research Grant NB04704 and from the Americn Cancer Society T-400, IN-9G and No. MH 10372-03.

63. The authors acknowledge the technical assistance of Sharon Schuffler and Carol Kolen.

64. Requests for reprints should be addressed to: IRA M.Rosenthal, M.D., Department of Pediatrics, University of Illinois College of Medicine, 840 South Wood Street, Chicago, IL 60612 (USA). 